\title{
24-Epibrassinolide as a Modifier of Antioxidant Activities and Membrane Properties of Wheat Cells in Zearalenone Stress Conditions
}

\author{
Maria Filek ${ }^{1}$ Apolonia Sieprawska ${ }^{2}$ Jana Oklestkova ${ }^{3}$ - Elżbieta Rudolphi-Skórska ${ }^{2}$. Jolanta Biesaga-Kościelniak ${ }^{1}$. \\ Zbigniew Miszalski ${ }^{1} \cdot$ Anna Janeczko $^{1}$
}

Received: 18 September 2017 / Accepted: 2 February 2018 / Published online: 23 February 2018

(c) The Author(s) 2018. This article is an open access publication

\begin{abstract}
The mechanism of action of brassinosteroids (BRs) in plant cells under stress has not been fully explained, despite ample evidence of their protective effects. The aim of this study was to investigate the significance of physicochemical properties of cell membranes during an interaction with BRs under stress conditions induced by a mycotoxin zearalenone (ZEA). Experiments were performed in in vitro cultures of wheat cells obtained from immature embryos of tolerant and sensitive genotypes. ZEA added to media $(30 \mu \mathrm{M})$ accumulated in greater amounts in the cells of sensitive wheat, contrary to BRs, which accumulated in greater amounts by the tolerant genotype when added to media at $0.1 \mu \mathrm{M}$. Incorporation of 24-epibrassinolide (EBR) stimulated synthesis of casta- and homocastasterone, that is, endogenous BRs present in wheat cells, and enhanced the content of homocastasterone. When the cultures were supplemented with the mixture of ZEA and EBR, castasterone synthesis was stimulated to a higher degree in cells of the sensitive plant. EBR and ZEA added separately activated antioxidant enzyme systems in both genotypes but with preference for the sensitive one. In the cells treated with ZEA + EBR, the activation was close to that observed for EBR alone. The study discussed also the role of membrane permeability, electrokinetic potential changes, and structural properties of native (plasmalemma) and model (DOPC) monolayers in the mechanism of EBR-induced protection, including the possibility of replacing ZEA absorbed in the membrane lipid layers by BR molecules, independently of the activation of the antioxidant system.
\end{abstract}

Keywords Brassinosteroids $\cdot$ Mycotoxin stress $\cdot$ Cereal $\cdot$ Antioxidative enzymes $\cdot$ Membrane structure

\section{Introduction}

One of the highlights of plant physiology research in the last decade was studies focusing on identification, characterization, and description of brassinosteroids (BRs), a group of hormones ubiquitously distributed in the plant kingdom (Bajguz and Tretyn 2003). Demonstration of BRs' capability

Maria Filek

mariafilek@excite.com

1 Institute of Plant Physiology, Polish Academy of Sciences, Niezapominajek 21, 30-239 Kraków, Poland

2 Institute of Biology, Pedagogical University, Podchorążych 2, 30-084 Kraków, Poland

3 Laboratory of Growth Regulators, Palacký University and Institute of Experimental Botany, ASCR, Šlechtitelů 27, 78371 Olomouc, Czech Republic of reducing stress-induced effects opened up a possibility for using these substances as natural plant-protection agents (Fariduddin and others 2014). Their properties are interesting from both agricultural and physiological points of view, as environmental stresses are still the main reason for reduced crop yield. Exogenous BRs have been so far applied to increase plant tolerance to chilling (Yu and others 2002; Liu and others 2009, 2011; Janeczko and others 2007), salt (Anuradha and Rao 2001; Ding and others 2012), heavy metals (Hayat and others 2014; Bajguz 2000; Bajguz and Hayat 2009), water stress (Yuan and others 2010), and pathogen infection (Nakashita and others 2003). However, the mechanism of their action is still not fully recognized. A variety of chemical structures of the so-far identified BRs (focused mainly on carbon and oxygen proportions) (Zullo and Adam 2002) suggested that they may stimulate different metabolic pathways, depending upon inducing factors (stressors). 
Identification and molecular characterization of specific membrane receptors mean that BRs bound by these receptors may alter plant metabolism in a way similar to other hormones (Malinowski and others 2009; Schumacher and Chory 2000). It was postulated that an interaction of BRs-ligands with receptors induced the activity of suitable kinase-domains, enhanced the activity of either other kinases and/or a yet unknown protein, and finally initiated a signaling system involved in stimulation of nucleic acid and new protein synthesis. However, the chemical similarity of BRs to membrane sterols suggests their direct localization in the hydrophobic part of lipid membranes and cooperation with sterols in modifying physical, chemical and structural properties of the membranes. On the other hand, BR stimulation of antioxidant agents ( $\mathrm{Li}$ and others 2016) indicated direct involvement of BRs in the mechanisms controlling cellular redox homeostasis. Increased activity of antioxidant enzymes responsible for deactivation of reactive oxygen species (ROS) was observed in plants cultured in BR presence (Verma and others 2012). Excessive generation of ROS is characteristic of oxidative stress, the final symptom of all abiotic and biotic stresses (Sharma and others 2012). Our earlier studies showed that BRs may enhance antioxidant activity also in plants exposed to a fungal (Fusarium) plant mycotoxin—zearalenone (Filek and others 2017).

Zearalenone is responsible for numerous diseases in a wide range of crops of economic importance (Gromadzka and others 2008; Infantino and others 2011; Ioos and others 2005). It is considered as one of the most destructive stressors difficult to reduce due to its persistence, wide range and broad geographical distribution (Doohan and others 2003). Accumulation of mycotoxins in plants is of special importance for global food production. Thus, identifying the mechanisms controlling the plant cell's ability to uptake this toxin could be helpful in choosing appropriate protective substances to use against this stressor.

Our previous studies demonstrated that a treatment with 24-epibrassinolide (EBR) diminished ZEA uptake by wheat seeds, and this protective effect of BR depended on plant genotype tolerance to oxidative stress (Filek and others 2017). This indicated that EBR presence might either block the place of ZEA adsorption in the domains of specific membrane receptors and/or replace this toxin location in the hydrophobic part of lipid layers. As ZEA reveals hormonal properties at very low concentrations (Biesaga-Kościelniak and Filek 2010), some ZEA-specific membrane receptors similar to those found in animal cells (Turcotte and others 2004) may also be present in plant cells. Our studies also showed that this toxin might penetrate membrane structure and enter the hydrophobic part of the membrane (Gzyl and others 2004; Gzyl-Malcher and others 2017). The similarity of the ZEA and BR chemical structure to sterols, essential membrane components, suggests similar mechanisms of BR and ZEA adsorption and transport into cells. Such a replacement or displacement of molecules with a potential ability to enter the membrane may explain the protective effects of BRs against ZEA. The possibility of BR absorption into the lipid structure of model membranes was studied in our unpublished work.

The aim of this study was to determine direct effects of both ZEA and BR on plant cells in in vitro cultures: (i) to indicate whether/to what concentration BR may be accumulated in ZEA presence in the cells and to what extent this process may stimulate antioxidant activity against this mycotoxin, and (ii) to verify the possibility of replacing ZEA with BR in lipid membranes. These findings may be helpful in explaining the mechanisms of BR protective actions in ZEAstressed plants. Membrane effects of both ZEA and EBR were determined in native and model membranes. Langmuir monolayers of model membranes allowed us to calculate physicochemical parameters of the membrane structure modified by the interactions with hydrophobic and hydrophilic reagents (Rudolphi-Skórska and Sieprawska 2016).

\section{Materials and Methods}

\section{Plant Material}

Grains of tolerant ('Parabola') and sensitive ('Raweta') spring wheat were obtained from Polish Plant Breeding Stations (Radzików and Strzelce, Poland) and their stress tolerance was determined in our earlier studies (Grzesiak and others 2013; Sieprawska and others 2014). The grains were sown in pots with a mixture of soil:peat:sand $(3: 2: 1$; $\mathrm{v} / \mathrm{v} / \mathrm{v})$ and cultured in a greenhouse at controlled conditions of temperature $\left(20 / 17^{\circ} \mathrm{C}\right.$; day/night), and light $(16 / 8 \mathrm{~h}$ day/ night) photoperiod, $400 \mu \mathrm{mol}$ (quantum $\mathrm{m}^{-2} \mathrm{~s}^{-1}$ light) until an appearance of anthers. Then, immature embryos were isolated and prepared for in vitro cultures, as described in details in another study (Filek and others 2009). After two months, stabilized cultures of undifferentiated callus cells were obtained on Murashige and Skoog (MS) (1962) medium supplemented with $2 \mathrm{mg} \mathrm{ml}^{-1}$ of 2,4-dichlorophenoxyacetic acid. Every 20 days, the calli were transferred onto new medium. The calli were used to investigate direct effects of ZEA and EBR on wheat cells.

In earlier experiments, a stress-inducing effect of ZEA on wheat cells was observed at a concentration of $30 \mu \mathrm{mol}$ (Gzyl-Malcher and others 2017) and the protective action of 24-epibrassinolide (EBR), a representative of BRs-at $0.1 \mu \mathrm{M}$ (Filek and others 2017). Thus, a similar amount of this mycotoxin was used in this study. Undifferentiated calli cells were cultured for 7 days on MS media supplemented with ZEA $(30 \mu \mathrm{M})$, EBR $(0.1 \mu \mathrm{M})$, or a mixture ZEA + EBR $(30 \mu \mathrm{M}+0.1 \mu \mathrm{M})$. For each variant, 12 Petri dishes (c.a. $1 \mathrm{~g}$ 
of callus fresh weight) were prepared. All treatments were repeated three times.

For selected experiments (ion leakage, electrokinetic potential, Langmuir monolayers), the control cells were shortly $(0.5 \mathrm{~h})$ incubated in media with ZEA, EBR, and $\mathrm{ZEA}+\mathrm{EBR}$ at the same concentrations as used during 7 days of in vitro cultures.

\section{Chemicals}

Zearalenone was obtained from Fermentek (Jerusalem, Israel), 24-epibrassinolide [24-epibrassinolide, (22R, 23R, 24R)-2 $\alpha, 3 \alpha, 22,23$-tetrahydroxy-24-methyl-B-homo-7-oxa$5 \alpha$-cholestane-6-one] was purchased from Sigma Aldrich Company (St. Louis, MO, USA). DOPC (1,2-dioleoyl-snglycero-3-phosphocholine) was received from Avanti Polar Lipids (Alabbaster, AL, USA) and other chemicals from Merck (Darmstadt, Germany). Water used as a subphase for monolayer formation was purified by a HLP 5 apparatus Hydrolab (Poland) to the resistance of approximately 18.2 $\mathrm{M} \Omega \mathrm{cm}^{-1}$.

\section{Biochemical analysis}

\section{Determination of Zearalenone Concentration}

Total content of ZEA in the callus cells was analyzed with an Ultra-High Performance Liquid Chromatography (UHPLC) apparatus (Infinity 1260, Agilent Technologies) coupled with a quadruple mass spectrometry detector (QQQ 6410), as described previously (Filek and others 2017; Gromadzka and others 2015). After extraction (2 g) with acetone:water (95:5; v:v), the samples were purified on a Bond Elut Mycotoxin column (45 mm/1000 mg, Agilent Technologies) and injected $(10 \mu \mathrm{l})$ onto an analytical column (Poroshell 120 phenyl-hexyl), where the mobile phase was a mixture of acetonitrile, water, and methanol (46:46:8, v/v/v) eluted at $0.3 \mathrm{ml} \mathrm{min}^{-1}$. A mass analyzer in monitoring ion mode with a positive ratio of atomic mass to charge was used.

\section{Analysis of Brassinosteroid Content}

BR analyses were performed according to Oklestkova and others (2017). Plant material (1 g fresh weight) was homogenized in ice-cold $80 \%$ methanol $(20 \mathrm{ml})$. The samples were centrifuged $\left(20 \mathrm{~min}, 4^{\circ} \mathrm{C}, 2000 \times g\right)$ and the supernatant was enriched in deuterium labeled BRs. Then, they were passed through Discovery columns (Supelco, Bellefonte, PA, USA), evaporated under vacuum to $3 \mathrm{ml}$ (Rotavapor R-215; BUCHI, Switzerland) and then to dryness under nitrogen at $40{ }^{\circ} \mathrm{C}$. After resuspending in $1 \mathrm{ml}$ of $7.5 \%$ methanol in phosphate buffered saline $\left(50 \mathrm{mM} \mathrm{NaH}_{2} \mathrm{PO}_{4}, 15 \mathrm{mM} \mathrm{NaCl}\right.$,
$\mathrm{pH}$ 7.2), the samples were passed through an immunoaffinity column (Laboratory of Growth Regulation, Olomouc, Czech Republic). Next, they were evaporated and dissolved in methanol. BRs were determined by UHPLC with tandem mass spectrometry (UHPLC-MS/MS), ACQUITY UPLCIClass System (Waters, Milford, MA, USA), in a triple quadrupole mass spectrometer Xevo ${ }^{\mathrm{TM}}$ TQ-S MS (Waters MS Technologies, Manchester, UK).

\section{Antioxidant Enzyme Extraction and Assays}

The callus samples of about $1 \mathrm{~g}$ were extracted with $1.5 \mathrm{~cm}^{3}$ of $0.1 \mathrm{M}$ potassium phosphate (KP) buffer containing $2 \mathrm{mM}$ $\alpha$-dithiothreitol, $0.1 \mathrm{mM}$ ethylenediaminetetraacetic acid (EDTA), and $1.25 \mathrm{mM}$ polyethylene glycol ( $\mathrm{pH} 7.8$ ), and after centrifugation at $14,000 \times g$ for $30 \mathrm{~min}$ at $4{ }^{\circ} \mathrm{C}$ (MPW 260R, Warszawa, Poland) the supernatant was purified on a PD10 column (Amersham Biosciences, Sweden). The supernatant was used for determination of protein content and enzymatic activity. Protein content was analyzed by the Bradford method (1976) using bovine serum albumin as a standard.

Activity of all enzymes was examined spectrometrically (Biochrom Ultrospec II, LKB, Sweden), using KINLAB software for determination of the reaction kinetics. Superoxide dismutase (SOD, EC 1.15.11) activity was registered at $\lambda=595 \mathrm{~nm}$ (McCord and Fridovich 1969); the activity of catalase (CAT, EC 1.11.16) was measured at $\lambda=240 \mathrm{~nm}$ (Aebi 1984); peroxidase (POD EC 1.11.1.7) activity was analyzed at $\lambda=485 \mathrm{~nm}$ (modified method of Lück 1965) and ascorbate peroxidase (APOX, EC 1.11.1.11) at $\lambda=290 \mathrm{~nm}$ (Nakano and Asada 1981). The activity of dehydroascorbate reductase (DHAR EC 1.8.5.1) was estimated at $\lambda=265 \mathrm{nM}$, according to a method of Dalton and others (1986); glutathione reductase (GR, EC 1.8.1.7) activity was assayed at $\lambda=340 \mathrm{~nm}$ as described earlier by Carlberg and Mannervik (1975); glutathione $S$-transferase (GST, EC 2.5.1.13) activity was examined at $\lambda=340 \mathrm{~nm}$ (Habig and Jacoby 1981); glutathione peroxidase (GPOX, EC 1.11.1.9) activity was established at $\lambda=340 \mathrm{~nm}$ (Flohé and Günzler 1984) and polyphenol oxidase (PPO, EC1.10.3.1) activity at $\lambda=495 \mathrm{~nm}$ (Kumar and Khan 1982).

\section{Lipid Extraction from the Callus Plasmalemma}

Plasmalemma of the calli cells were obtained as described by Gzyl-Malcher and others $(2007,2017)$ in a solution of $250 \mathrm{mM}$ sucrose, $2.5 \mathrm{mM}$ dithiothreitol, $1 \mathrm{mM}$ phenylmethylsulfonyl fluoride, 1M EDTA, and $10 \mathrm{mM}$ Tris (pH 7.5). Lipids were isolated according to the Blight and Dyer (1959) method with Filek and others (2005) modification in the chloroform:isopropanol (1:1) mixture. Fractions of polar lipids were divided using adsorptive and distributive column 
chromatography and purified by thin-layer chromatography (Block and others 1983). Fatty acid analysis was performed by gas chromatography (Hewlett Packard, USA) equipped with a capillary column $(30 \mathrm{~m} \times 0.25 \mathrm{~mm})$ and heptadecanoic (17:0) acid as an internal standard. Phospholipids, as the most abundant polar fraction, were used in model membrane analysis.

\section{Malondialdehyde (MDA) Determination}

Callus cells (c.a. $1 \mathrm{~g}$ ) were homogenized in $0.5 \%$ trichloroacetic acid (TCA) and after centrifugation $(10,000 \times g$; 10 min; Micro 185, Hettich, Tuttingen, Germany), MDA concentration was determined as described in detail by Dhindsa and others (1981) and Tobiasz and others (2014).

\section{Electrolyte Conductivity Measurements}

Membrane permeability was measured conductometrically based on electrolyte leakage from cells. About $3 \mathrm{~g}$ of calli from each studied media was washed twice and incubated in $0.6 \mathrm{M}$ mannitol solution to preserve the same osmotic conditions as inside the cell, or in the same solution supplemented with ZEA $(30 \mu \mathrm{M})$, EBR $(0.1 \mu \mathrm{M})$ or a mixture of ZEA + EBR $(30 \mu \mathrm{M}+0.1 \mu \mathrm{M})$ to observe the immediate effects of these substances. After $0.5 \mathrm{~h}$-incubation (at $20{ }^{\circ} \mathrm{C}$ ), electrolyte leakage was registered by a conductometer (Elmenton CX 505, Zabrze, Poland) and denoted as the membrane permeability $(L 1)$. Next, the calli were boiled at $100{ }^{\circ} \mathrm{C}$ for $15 \mathrm{~min}$ to determine total cellular leakage ( $\left.L 2\right)$. The values of ion leakage were calculated as relative permeability $[\mathrm{EL}(\%)=(L 1 / L 2) \times 100]$ according to Filek and others (2004).

\section{Electrokinetic Potential Measurements}

Electrokinetic potentials were determined for protoplast membranes of callus cells as described earlier by Filek and others (2002). Electrokinetic potential measurements were made in a media of defined ionic strength $(0.1 \mathrm{mM} \mathrm{KCl})$ and constant osmotic pressure ( $0.6 \mathrm{M}$ mannitol). For protoplasts obtained from calli cultured in control conditions, additional analyses were performed in which ZEA $(30 \mu \mathrm{M})$ and EBR $(0.1 \mu \mathrm{M})$ were added separately and as a mixture into the measuring media. The electrokinetic potential values were calculated from electrophoretic mobility data (according to Smoluchowski equation) using Zeta-PLUS apparatus (Brookhaven, USA).

\section{Langmuir Monolayers}

The model membranes were prepared in a Langmuir trough (NIMA, Coventry, UK) and physicochemical parameters of membrane monolayers were obtained from surface pressure $(\pi)$ versus molecule area $(A)$ dependence (Rudolphi-Skórska and others 2014; Gzyl-Malcher and others 2017). The monolayers were obtained by spreading chloroform solution of appropriate phospholipids (PL) (extracted from calli cultured on the media with EBR or/and ZEA) on the water subphase. In the case of PL isolated from calli cultured in control conditions, lipids or lipid-EBR mixtures (4:1; mol:mol) were placed on water or ZEA $(30 \mu \mathrm{M})$ aqueous solution as a subphase. Additionally, for pure DOPC monolayers, the mixtures of DOPC-ZEA and DOPC-EBR at a concentration of 0:1, 0.2:0.8, 0.4:0.6, 0.6:0.4, 0.8:0.2, and 1:0 were used to calculate thermodynamic function of the interaction of ZEA and EBR with PL layers (excess of free energy of mixing $\Delta G^{\mathrm{EXC}}$ ) according to Birdi (1989)

$\Delta G^{\mathrm{EXC}}=N_{\mathrm{A}} \int_{0}^{\pi_{2}}\left(A_{12}-x_{1} A_{1}-x_{2} A_{1}\right) \mathrm{d} \pi$,

where $N_{\mathrm{A}}$-Avogadro's number, $A_{1}, A_{2}$, and $A_{12}$-mean molecular area of components 1 and 2 and their mixture, respectively, $x_{1}$ and $x_{2}$-mole fractions of the mixture components. The accuracy of $\pi$ was $\pm 0.1 \mathrm{mN} \mathrm{m}^{-1}$. The experiments were repeated three or four times to ensure high reproducibility of the isotherms.

\section{Statistical Analysis}

All experiments were repeated at least three to four times, and each experiment included at least triplicate treatments. The data are presented as mean $\pm \mathrm{SE}$ and were analyzed statistically using a SAS ANOVA procedure. Comparisons of mean values were analyzed using Duncan's multiple range tests with PC SAS 8.0. Differences with $p$ values lower than 0.05 were considered significant.

\section{Results}

\section{Zearalenone and 24-Epibrassinolide Content}

Callus cells of both Parabola and Raweta genotypes cultured on the control media (without ZEA and EBR supplementation) contained ZEA in similar, trace amounts (Fig. 1). Application of ZEA increased repeatedly accumulation of this toxin in both types of cells. In the presence of EBR + ZEA-supplemented media, the uptake of ZEA decreased by about $40 \%$ in Parabola cells and by about $35 \%$ in Raweta cells as compared with the cells treated with ZEA alone.

The analysis of BR content showed that in the control conditions the calli contained mainly homocastasterone and 
Fig. 1 Concentration of zearalenone (ZEA) in calli cells of tolerant (Parabola) and sensitive (Raweta) wheat cultured for 7 days at MS media (control) and at media supplemented additionally with 24-epibrassinolide (EBR), ZEA and the mixture of ZEA + EBR. The data are the means of three independent biological replications \pm SE. Different letters indicate significant differences between used treatments $(p \leq 0.5)$

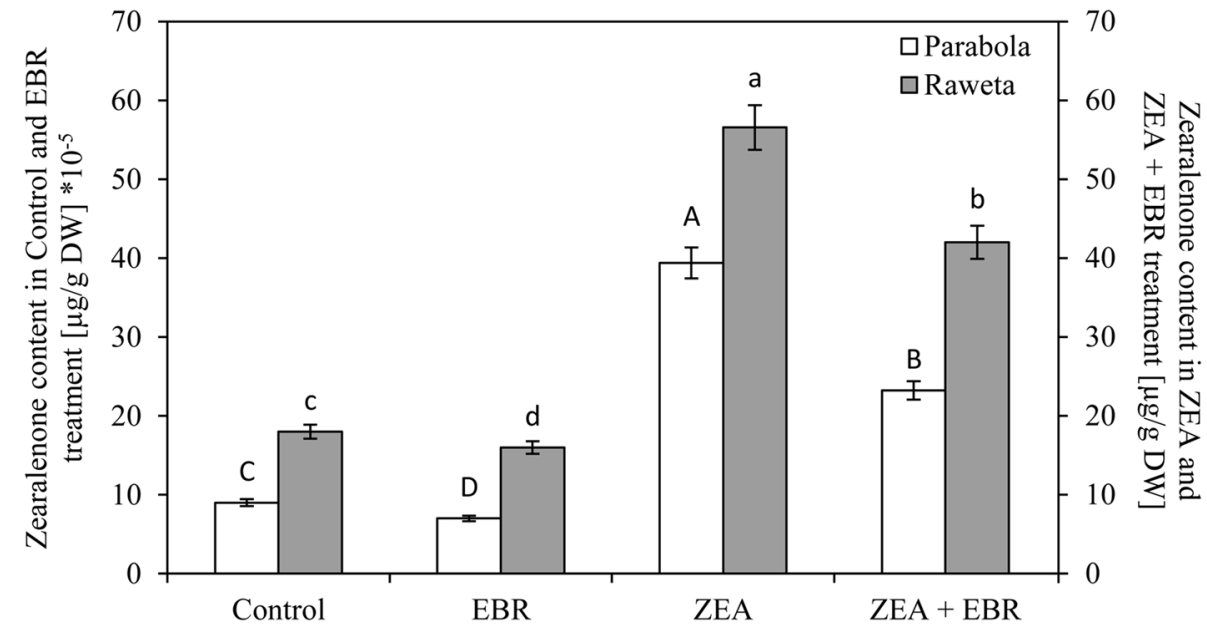

\begin{tabular}{lllll}
\hline Treatment $(\mu \mathrm{M})$ & $\begin{array}{l}\text { 24-Epibrassi- } \\
\text { nolide }(\mathrm{pM} / \mathrm{g} \mathrm{FW})\end{array}$ & Castasterone (pM/g FW) & $\begin{array}{l}\text { Homocastasterone } \\
(\mathrm{pM} / \mathrm{g} \mathrm{FW})\end{array}$ & $\begin{array}{l}\text { Homocastas- } \\
\text { terone/castas- } \\
\text { terone }\end{array}$ \\
\hline $\begin{array}{l}\text { Parabola } \\
\text { Control }\end{array}$ & $\mathrm{ND}$ & & & \\
EBR & $209.27 \pm 7.95^{\mathrm{a}}$ & $0.35 \pm 0.07^{\mathrm{b}}$ & $3.11 \pm 0.06^{\mathrm{c}}$ & $3.67 \pm 0.25^{\mathrm{b}}$ \\
ZEA+EBR & $153.17 \pm 5.47^{\mathrm{b}}$ & $0.49 \pm 0.08^{\mathrm{a}}$ & $2.11 \pm 0.04^{\mathrm{b}}$ & $4.31 \pm 0.23^{\mathrm{b}}$ \\
Raweta & & & & \\
Control & $\mathrm{ND}$ & $0.30 \pm 0.03^{\mathrm{a}}$ & $1.08 \pm 0.05^{\mathrm{b}}$ & $3.60 \pm 0.21^{\mathrm{c}}$ \\
EBR & $121.72 \pm 6.59^{\mathrm{a}}$ & $0.38 \pm 0.05^{\mathrm{a}}$ & $9.86 \pm 0.98^{\mathrm{a}}$ & $25.94 \pm 1.09^{\mathrm{b}}$ \\
ZEA+EBR & $117.29 \pm 6.75^{\mathrm{a}}$ & $0.28 \pm 0.04^{\mathrm{ab}}$ & $9.29 \pm 1.02^{\mathrm{a}}$ & $33.18 \pm 1.20^{\mathrm{a}}$ \\
\hline
\end{tabular}

$N D$ not detected

Data are averages from three independent biological replications \pm SE. The same letters indicate not significant differences between treatments for the individual brassinosteroids, registered separately for each wheat

genotype $(p \leq 0.5)$
Table 1 Content of

brassinosteroids in calli cells of tolerant (Parabola) and sensitive (Raweta) wheat cultured for 7 days at MS media (control) and at media supplemented with 24-epibrassinolide (EBR), zearalenone (ZEA), and the mixture of ZEA + EBR castasterone (Table 1). The level of these BRs was similar in both genotypes, with about threefold higher level of homocastasterone. EBR introduced into the media increased mainly homocastasterone content. This effect was more pronounced in Raweta cells despite lower uptake of EPR in this genotype. The ratio of homo-/castasterone was about threefold higher in Raweta in comparison with Parabola, and the level of castasterone was similar in both varieties. When ZEA was added to the media together with EBR, accumulation of EBR decreased in the cells of both genotypes, whereas the ratio of homo-/castasterone decreased in Parabola, and increased in Raweta, as compared with EBR only treatment (Fig. 2).

\section{Activity of Antioxidant Enzymes}

EBR supplementation activated all investigated enzymes in both types of calli, except for POD, where an inhibitory reaction was observed (Fig. 3). Generally, the induction was stronger in Raweta cells. When ZEA was present in the

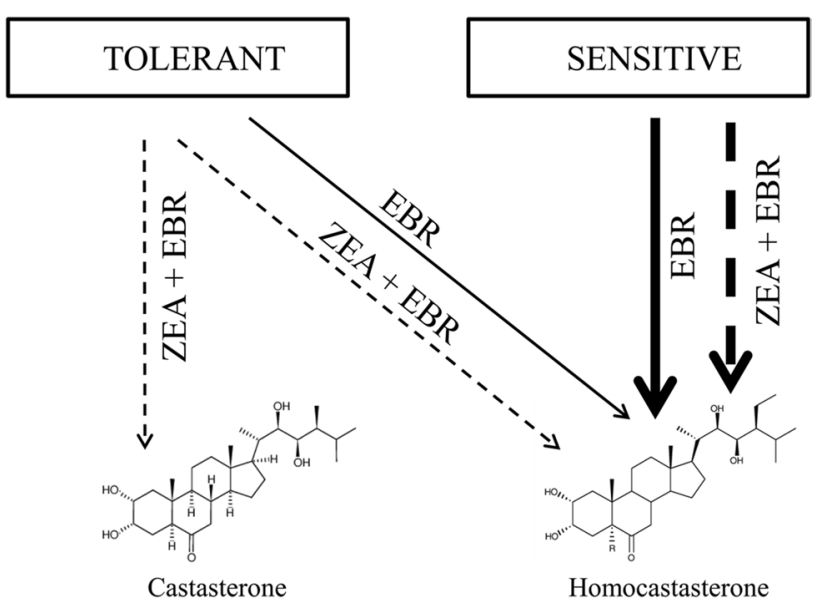

Fig. 2 A descriptive model of EBR and ZEA + EBR action on castasterone and homocastasterone synthesis in cells of tolerant and sensitive wheat calli 

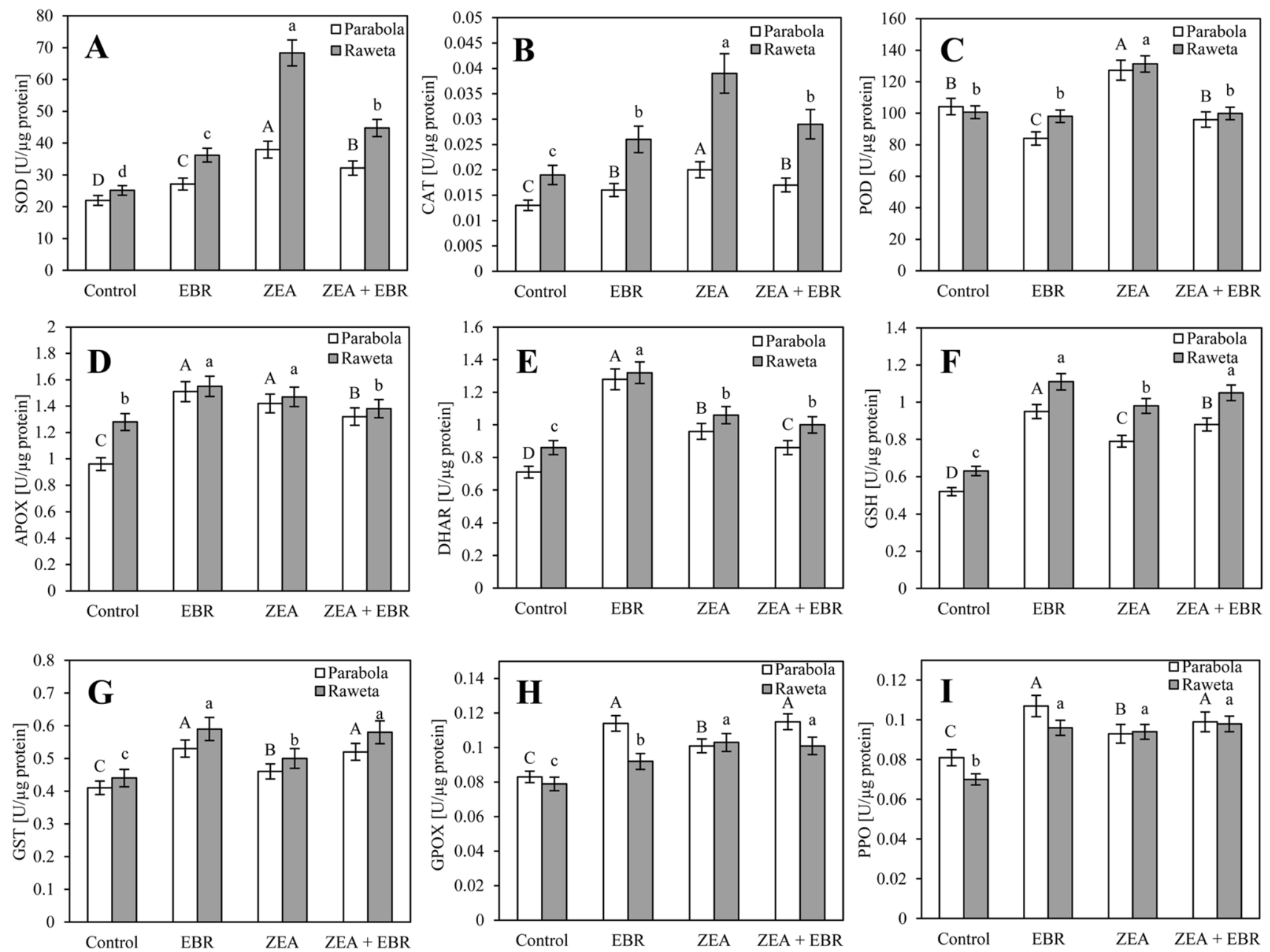

Fig. 3 Effect of 24-epibrassinolide (EBR), zearalenone (ZEA), and the mixture of ZEA + EBR treatment on the antioxidants activity (U/g of protein) in calli cells of tolerant (Parabola) and sensitive (Raweta) wheat cultured at MS media. Control—not treatment cells. SOD superoxide dismutase (a), CAT catalase (b), POD peroxidase (c),

media, SOD and CAT activities were also enhanced significantly especially in Reweta where they increased more than two times as compared with control (Fig. 3a, b). POD activity was higher than in the control cells by about 22 and $30 \%$ for Parabola and Raweta variants, respectively (Fig. 3c). The presence of ZEA more intensively enhanced other enzyme activity in Raweta than in Parabola cells; however, the changes were at slightly lower levels than those registered for EBR only treatment (Fig. 3d, e, f, g, h, i). Application of both ZEA + EBR activated mainly SOD in Parabola cells and this response was strongest when EBR was present separately in the media. Enhanced SOD activity (in comparison with control and EBR) was also observed in Raweta cells but this effect was weaker than for the ZEA only variant. CAT activity was at a similar level to EBR treatment in both Parabola and Raweta cells. As for other enzymes, their
APOX ascorbate peroxidase (d), DHAR dehydroascorbate reductase (e), GSH reduced glutathione (f), GST glutathione S-transferase (g), GPOX glutathione peroxidase (h), PPO polyphenol oxidase (i). The data are the means of ten replicates \pm SE. Different letters indicate significant differences between used treatments $(p \leq 0.5)$

activity in Parabola cells grown on ZEA + EBR media was similar (for POD), or higher than in controls. In Raweta, the changes in DHAR, GSH, GST, GPOX, and PPO activity were similar to the media supplemented only with ZEA or EBR separately, and greater than those in control cells. POD activity was similar to that in the control cells of both genotypes.

\section{Properties of the Natural Membranes}

Chromatographic analysis indicated that the main fatty acids in the PL fraction isolated from plasmalemma of Parabola cells cultured on the control media were, at mol \% concentration, palmitic acid (16:0) at $13.9 \pm 0.2 \%$, stearic acid (18:0) at $1.2 \pm 0.1 \%$, oleic acid (18:1) at $25.4 \pm 0.3 \%$, linoleic acid (18:2) at $36.1 \pm 0.4 \%$, and linolenic acid (18:3) 
at $23.4 \pm 0.4 \%$. Plasmalemma of Raweta cells contained $16: 0$ acid at $14.1 \pm 0.1 \%, 18: 0$ acid at $2.6 \pm 0.1 \%, 18: 1$ acid at $27.5 \pm 0.4 \%, 18: 2$ acid at $36.2 \pm 0.2 \%$, and $18: 3$ acid at $19.6 \pm 0.4 \%$. EBR and ZEA separately added to the media reduced unsaturation of plasmalemma fatty acids (a ratio of un-/saturated fatty acids; U/S) in both wheat genotypes (Fig. 4a). This relation was more visible for ZEA treatment and in Raweta cells. When EBR was added together with ZEA, unsaturation increased in the membranes of both types of calli to the level close to that found for EBR.

MDA content, a parameter denoting the degree of membrane lipid peroxidation, was higher for Parabola than for Raweta cells in all treatments (Fig. 4b). When used separately, the investigated substances increased MDA amount
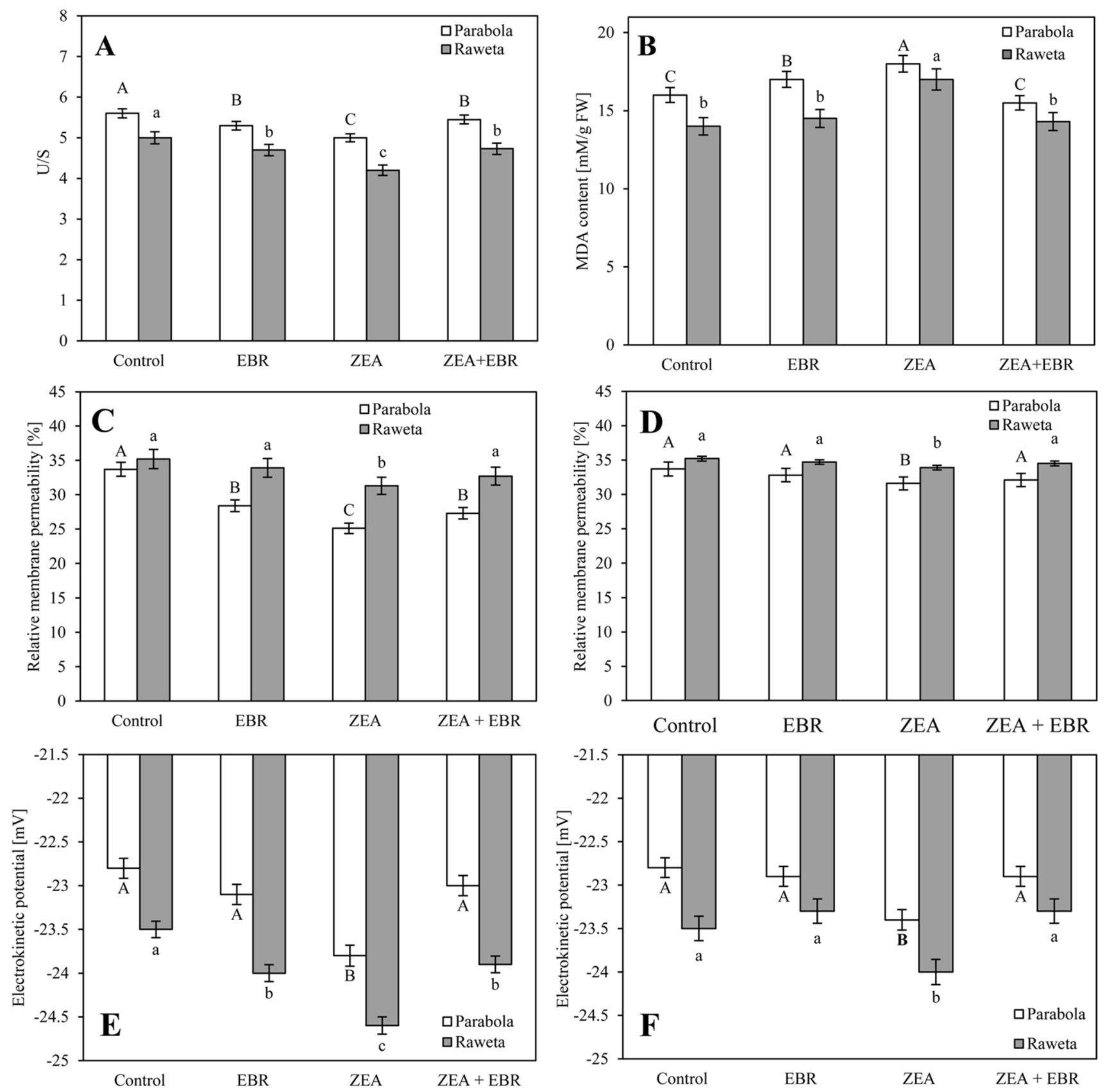

Fig. 4 Effect of 24-epibrassinolide (EBR), zearalenone (ZEA), and the mixture ZEA + EBR treatment on cells of tolerant (Parabola) and sensitive (Raweta) wheat. The lipid unsaturation calculated as a ratio of un- to saturated fatty acids, U/S (a), malondialdehyde (MDA) content (b), membrane permeability after 0.5 -h treatment (c) or after 7

days culture (d) and electrokinetic potential after 0.5-h treatment (e) or after 7 days culture (f). Control-not treatment cells. The data are the means of three independent biological replications \pm SE. Different letters indicate significant differences between used treatments $(p \leq 0.5)$ 
in comparison with control. The mixture of ZEA + EBR reduced MDA content in comparison to that registered during addition of individual substances, but in Raweta cells the content of MDA was still slightly higher than in control.

Membrane permeability, calculated as a percentage of total ion leakage from cells, was greater in Raweta than in Parabola cells (Fig. 4c, d). Both short (0.5 h) (Fig. 4c) and long (7 days) (Fig. 4d) treatments with EBR and ZEA separately decreased the permeability with greater effect in Parabola and in ZEA presence. When the reagents were added together, values similar to those obtained for EBR alone were registered. Generally, greater effects of the investigated substances were visible after their shorter $(0.5 \mathrm{~h})$ presence in the media.

Similarly, more pronounced changes after shorter treatment with EBR and ZEA were found for electrokinetic potential (Fig. 4e, f). Plasmalemma of Raweta calli had slightly higher negative electrokinetic potentials than Parabola in all cases. Separate application of EBR and ZEA directly to the measuring medium $(0.5 \mathrm{~h})$ lowered the electrokinetic potential, especially in Raweta cells and in the presence of ZEA (Fig. 4E). When the cells were treated with a combination of ZEA + EBR, their electrokinetic potential was close to that recorded for EBR alone.

\section{Model Membranes}

Changes related to the interaction of the investigated substances with phospholipids present in membranes were measured in model lipid-monolayers by the Langmuire technique. Figure 5a presents example isotherms obtained for PL fraction isolated from Parabola calli cultured with

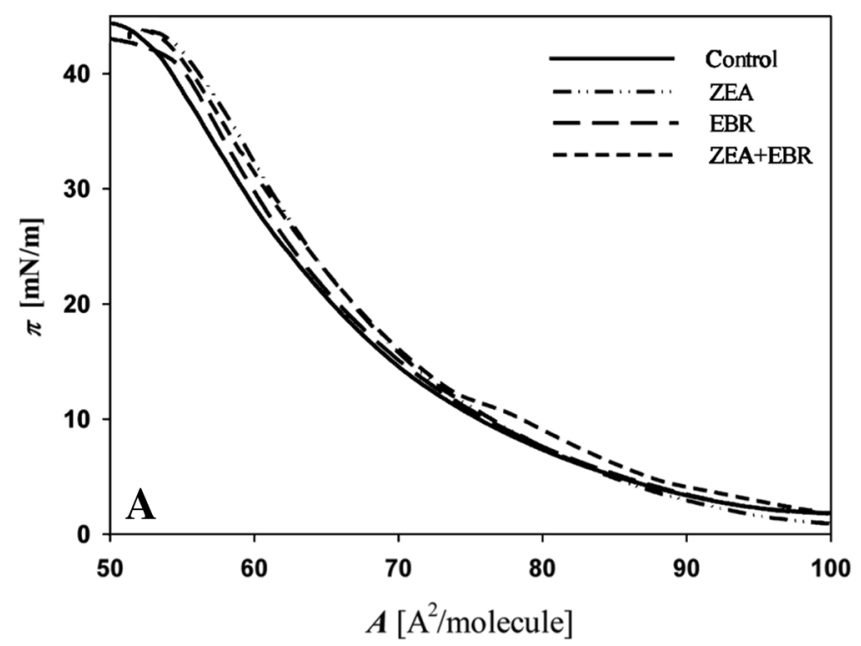

Fig. 5 Examples of the surface pressure $(\pi)$-area per molecule (a) isotherms recorded for phospholipids extracted from plasmalemma of Parabola calli cells cultured at control (MS) and MS media with EBR, ZEA, and the mixture of ZEA+EBR (a). b DOPC (1,2-dio-
ERB, ZEA, and ZEA + EBR. The isotherm shapes were the same as those registered for PL of the control calli, with an exception of those received for PL of the calli cultured on ZEA + EBR media, where a plateau on $\pi$ versus $A$ was visible. The isotherms were used to calculate physicochemical parameters of the membrane surface, that is, limiting area $\left(A_{\text {lim }}\right)$ representing the minimal area occupied by a molecule in the monolayer, and $C_{\mathrm{s}}^{-1}$ which denoted $\mathrm{d} \pi / \mathrm{d} A$ relationship describing membrane compressibility (Table 2). In Parabola control cells, the values of $A_{\text {lim }}$ were slightly higher than in Raweta (by about $1.8 \AA^{2}$ ). When EBR and ZEA were added separately to the culture media, this surface parameter of lipids increased (in comparison with control) by about 1.5 and $0.9 \AA^{2}$ for Parabola and Raweta, respectively, in EBR

Table 2 Physiochemical parameters of structure of the phospholipid monolayers obtained from plasmalemma of tolerant (Parabola) and sensitive (Raweta) wheat calli cells

\begin{tabular}{llllrl}
\hline Treatment & \multicolumn{2}{c}{$A_{\lim }\left(\AA^{2}\right)$} & & \multicolumn{2}{c}{$C_{\mathrm{s}}^{-1}\left(\mathrm{mN} \mathrm{m}^{-1}\right)$} \\
\cline { 2 - 3 } \cline { 5 - 6 } & Parabola & Raweta & & Parabola & \multicolumn{1}{l}{ Raweta } \\
\hline Control & $72.8 \pm 0.1^{\mathrm{d}}$ & $71.0 \pm 0.1^{\mathrm{d}}$ & & $117.6 \pm 0.5^{\mathrm{a}}$ & $120.3 \pm 0.4^{\mathrm{a}}$ \\
EBR & $74.3 \pm 0.2^{\mathrm{c}}$ & $71.9 \pm 0.1^{\mathrm{c}}$ & & $107.2 \pm 0.4^{\mathrm{b}}$ & $115.5 \pm 0.4^{\mathrm{b}}$ \\
ZEA & $75.9 \pm 0.3^{\mathrm{a}}$ & $74.5 \pm 0.2^{\mathrm{a}}$ & & $78.9 \pm 0.2^{\mathrm{d}}$ & $89.1 \pm 0.3^{\mathrm{d}}$ \\
ZEA+EBR & $74.9 \pm 0.1^{\mathrm{b}}$ & $72.4 \pm 0.2^{\mathrm{b}}$ & & $91.7 \pm 0.2^{\mathrm{c}}$ & $90.4 \pm 0.3^{\mathrm{c}}$ \\
\hline
\end{tabular}

Calli were cultured at MS media (control) and at media supplemented with 24-epibrassinolide (EBR), zearalenone (ZEA), and mixture ZEA +EBR for 7 days. $A_{\text {lim }}$-limiting area, $C_{\mathrm{s}}{ }^{-1}-$ maximum of monolayer compression. For more details see "Material and Methods." Data are averages from three independent biological replications \pm SE. The same letters indicate not significant differences between treatments separately for each wheat genotype $(p \leq 0.5)$

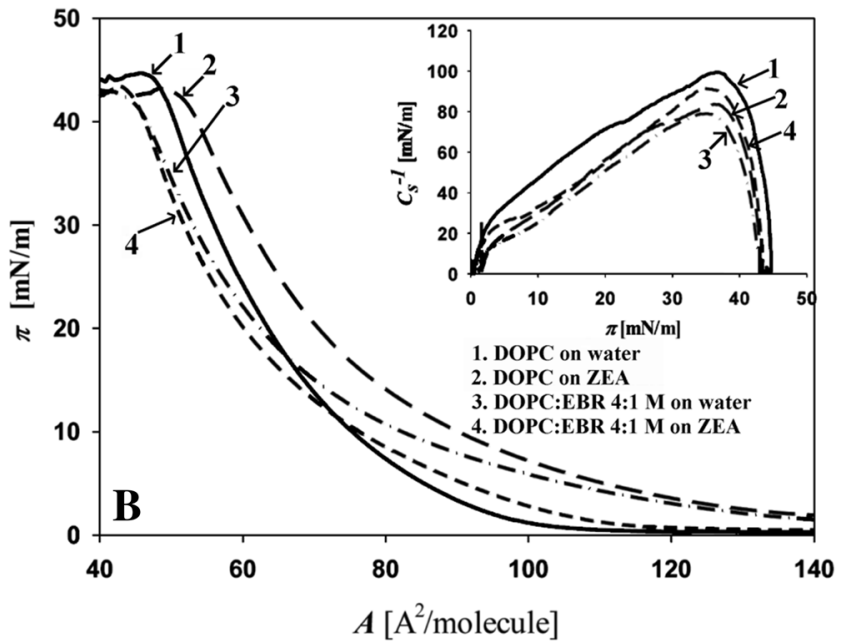

leoyl-sn-glycero-3-phosphocholine) and DOPC +EBR monolayers spread on water and water supplemented with ZEA subphases. Inset: $C_{\mathrm{s}}^{-1}$ versus $\pi$ 
supplemented media, and by about 3.1 and $3.5 \AA^{2}$ for these types of calli, respectively, in ZEA-supplemented media. In the cells treated with ZEA +EBR, the values of $A_{\text {lim }}$ decreased to those close to EBR. The opposite tendency was perceived for $C_{\mathrm{s}}^{-1}$ values, indicating an increase of membrane packing in the cells cultured in the presence of the investigated substances. Major changes calculated for the membranes of Parabola cells indicated greater effect of these substances on structural properties of this genotype.

To calculate a simultaneous reaction of ZEA and EBR with phospholipids, the monolayers were also prepared from DOPC (Fig. 5b). This phospholipid was chosen as a representative model of the lipid that is present in the highest proportion in natural cellular membranes of plants and animals (Hac-Wydro and others 2007). In comparison to pure DOPC being in contact with the water phase, ZEA presence in the water increased the monolayer surface of this lipid by about $10 \AA$ (Table 3). When DOPC was mixed with EBR (4:1 mol:mol) and its chloroform solution was spread on the surface, the area of such monolayer decreased by about $1.5 \AA$ (compared to that created with DOPC alone). After ZEA addition to the water subphase, the area of DOPC + EBR mixture was greater by about $3 \AA$ than when such a mixture was spread on pure water.

To determine the possibility of an interaction between ZEA and EBR inside lipid membranes, monolayers of DOPC + EBR (4:1 mol:mol) and DOPC + ZEA (4:1 mol:mol) were mixed in different proportions from DOPC + EBR (1:0) through DOPC + EBR:DOPC + ZEA $(0.8: 0.2,0.6: 0.4,0.4: 0.6$, and 0.2:0.8) to DOPC + ZEA $(0: 1)$ and spread on the water subphase. ZEA added alone into the lipid monolayer increased $A_{\lim }$ to a greater extent than EBR alone (Table 4). Increasing EBR content in the monolayer (as compared with ZEA) enhanced compression of the monolayer as indicated also by $C_{\mathrm{s}}^{-1}$ values.

Experiments with the preparation of DOPC monolayers in different mixtures of EBR and ZEA at four values of surface pressure $\left(5,10,20\right.$, and $\left.30 \mathrm{mN} \mathrm{m}^{-1}\right)$ allowed

Table 3 Physiochemical parameters of structure monolayers of dioleoyl L- $\alpha$-phosphatidylcholine (DOPC) and the mixture of DOPC with EBR $(4: 1 ;$ mol:mol) spread on the pure water subphase and on the water solution of zearalenone (ZEA, $15 \mu \mathrm{M}$ )

\begin{tabular}{lll}
\hline Monolayer/subphase system & $A_{\lim }\left(\AA^{2}\right)$ & $C_{\mathrm{s}}^{-1}\left(\mathrm{mN} \mathrm{m}^{-1}\right)$ \\
\hline DOPC/water & $70.7 \pm 0.2^{\mathrm{c}}$ & $98.3 \pm 0.2^{\mathrm{a}}$ \\
DOPC/ZEA solution & $80.6 \pm 0.2^{\mathrm{a}}$ & $83.6 \pm 0.2^{\mathrm{c}}$ \\
DOPC +EBR/water & $71.2 \pm 0.1^{\mathrm{d}}$ & $89.9 \pm 0.2^{\mathrm{b}}$ \\
DOPC +EBR/ZEA solution & $73.6 \pm 0.2^{\mathrm{b}}$ & $79.3 \pm 0.1^{\mathrm{d}}$ \\
\hline
\end{tabular}

$A_{\text {lim }}$-limiting area, $C_{\mathrm{s}}^{-1}$-maximum of monolayer compression

For more details see "Material and Methods." Data are averages from three independent biological replications \pm SE. Different letters indicate significant differences between used treatments $(p \leq 0.5)$
Table 4 Physiochemical parameters of monolayers of DOPC in the mixture with EBR (A) and with ZEA (B), both in 4:1 (mol:mol) proportions, spread on the water subphase

\begin{tabular}{lll}
\hline $\begin{array}{l}\text { Monolayer system of the } \\
\text { mixtures A:B }\end{array}$ & $A_{\lim }\left(\AA^{2}\right)$ & $C_{\mathrm{s}}^{-1}\left(\mathrm{mN} \mathrm{m}^{-1}\right)$ \\
\hline $0: 1$ & $66.8 \pm 0.1^{\mathrm{e}}$ & $73.5 \pm 0.2^{\mathrm{e}}$ \\
$0.2: 0.8$ & $66.2 \pm 0.1^{\mathrm{d}}$ & $83.3 \pm 0.3^{\mathrm{d}}$ \\
$0.4: 0.6$ & $67.1 \pm 0.2^{\mathrm{c}}$ & $87.7 \pm 0.2^{\mathrm{c}}$ \\
$0.6: 0.4$ & $69.0 \pm 0.1^{\mathrm{b}}$ & $92.7 \pm 0.3^{\mathrm{a}}$ \\
$0.8: 0.2$ & $69.6 \pm 0.2^{\mathrm{a}}$ & $91.3 \pm 0.2^{\mathrm{b}}$ \\
$1: 0$ & $69.6 \pm 0.2^{\mathrm{a}}$ & $91.8 \pm 0.3^{\mathrm{b}}$ \\
\hline
\end{tabular}

The additional monolayer systems were obtained by the mixing of $\mathrm{A}$ and $\mathrm{B}$, in the adequate proportion, to obtain monolayers with various amounts of EBR and ZEA in lipid phase. For more details see "Material and Methods." Data are averages from three independent biological replications \pm SE. Different letters indicate significant differences between used treatments $(p \leq 0.5)$

us to calculate the excess free energy of mixing $\Delta G^{\mathrm{MIX}}$ (Fig. 6). The values of this parameter increased with increasing ZEA content in the ZEA + EBR mixture and with the increasing of surface pressure. Positive effects were obtained for all mixed monolayers, except for the one when negative values were obtained for low EBR content in the ZEA + EBR mixture. In general, lower values of $\Delta G^{\mathrm{MIX}}$ were achieved for smaller area pressures of the monolayers (5 and $10 \mathrm{mN} \mathrm{m}^{-1}$ ), corresponding to weaker interactions between lipids.

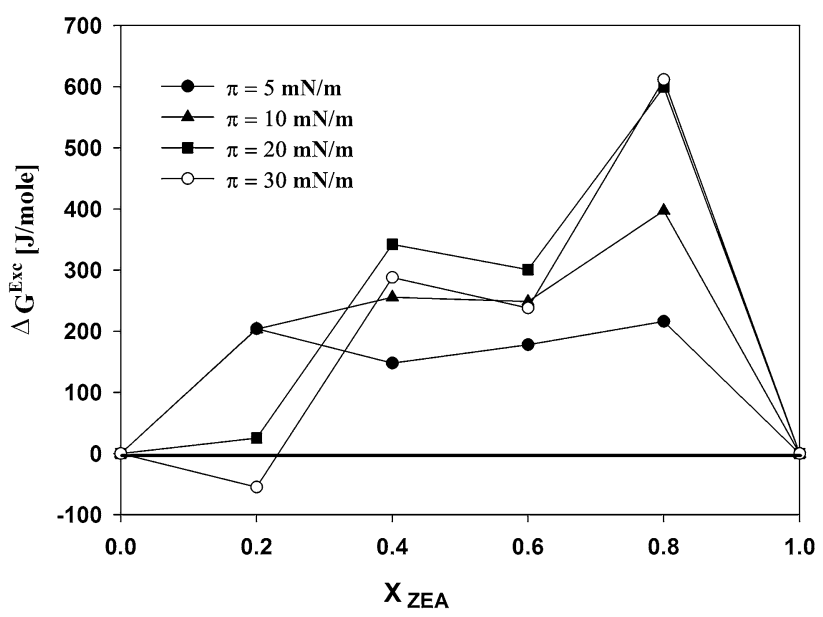

Fig. 6 The variation of excess free energy of mixing $\left(\Delta G^{\mathrm{EXC}}\right)$ versus molar fractions of ZEA presented in different molar ratios in the mixture of DOPC + ZEA and DOPC + EBR spread on water at four surface pressures: $5,10,20$, and $30 \mathrm{mN} \mathrm{m}^{-1}$ 


\section{Discussion}

Studies of direct interaction of ZEA with cell membranes of wheat cells performed in in vitro indicated that the tolerant genotype (Parabola) accumulated smaller amounts of this toxin than the sensitive one (Raweta) but this difference was not as significant as that found in the grains of both genotypes (Filek and others 2017). This demonstrated that the seed coat is a barrier preventing this toxin uptake by wheat grains, and that it was more effective in the tolerant than in the sensitive genotype. Choosing the specific biological object (non-organized cells) allowed us to expose the importance of physicochemical properties of the membranes in the interaction with both ZEA and EBR. It was interesting that EBR, despite some similarity in its chemical structure to ZEA, was more effectively absorbed by tolerant wheat than ZEA. The most abundant BRs in control calli of both genotypes were casta- and homocastasterone, with a significant dominance of the latter. Castasterone was also detected in a study by Janeczko and Swaczynova (2010) and Janeczko and others (2010) in wheat seedlings; however, they detected other BRs (not homocastasterone), such as EBR and brassinolide, in their plant material. Moreover, they observed that the presence and content of different BRs in wheat seedlings depended on the plant tissue (different BRs levels in various leaves; Janeczko and Swaczynova 2010). Castasterone is a product of brassinosteroid biosynthesis from campesterol that may be oxidized in various pathways depending on the stimulated genes (Chung and Choe 2013). This BR was indicated as a precursor of brassinolide, the most oxidized, and the most biologically active form among BRs (Suzuki and others 1993; Kim and others 2005). Homocastasterone is synthesized from sitosterol and may be converted to castasterone (Joo and others 2015). EBR-induced increase of only homocastasterone content (without changes in castasterone levels) observed in wheat calli suggested that EBR presence may particularly stimulate synthesis of this BR. It is worth pointing out that this process was activated to a considerably greater degree in the sensitive cells than in the tolerant calli. This suggests stress tolerancerelated differences in the activation of these BR-pathways (Fig. 2). When ZEA was added with EBR, a synthesis of both native BRs was stimulated in a similar way in tolerant calli (resulting in the same homo-/castasterone ratio as in control), whereas in the sensitive calli a decrease in their synthesis was observed in comparison with EBRtreatment. This indicates the differences in the stimulation of both BR synthesis pathways that depend also on the presence of stress factors.

Accumulation of greater amounts of BRs in the cells of the tolerant genotype seems to be beneficial for the plants. Presumably, the presence of such organic molecules potentially undergoing oxidation is an alternative to oxidation of proteins and lipids (physiologically important structures), and may serve as acceptors of electrons from ROS generated in stress conditions. The importance of biomolecules containing groups capable of "trapping" free electrons (such as polysaccharides), in the mechanism of oxidative stress tolerance (so-called "long-lived radicals"), was indicated by Łabanowska and others (2013). Thus, higher amounts of EBR and castasterone in the tolerant genotype may serve as potential "long-lived radicals" for deactivation of ROS generated in ZEA-induced oxidative stress, as suggested before (Filek and others 2017). Smaller changes in the activation of antioxidant enzymes, the indirect factors in the estimation of ROS generation intensity, observed in cells of tolerant calli may be the consequence of partial stabilization of ROS by BR structures.

Another possibility of BRs reaction with ROS, and particularly with $\mathrm{H}_{2} \mathrm{O}_{2}$, is an involvement of this ROS molecule in transcriptional induction of defense/antioxidant genes stimulated by these hormones (Xia and others 2009). This concept is based on the research claiming that low levels of ROS may play regulatory functions in plant stress responses (Gill and Tuteja 2010). Detailed studies of the relationships between BRs treatment and the activity of antioxidant enzymes in wheat calli indicated a stimulation of these antioxidant reactions in response to EBR presence. Greater changes in enzyme activity registered in the sensitive calli, where BRs were present in smaller amounts than in the tolerant cells, suggested indirect ROS-BR relationships. However, the increase in CAT, APOX, and POD levels and associated increase in DHAR mediating a reduction in $\mathrm{H}_{2} \mathrm{O}_{2}$ content (mainly by ascorbic-glutathione pathway) suggested EBR-induced stimulation of hydrogen peroxide synthesis. Also, the activation of other enzymes, such as GST and GPOX participating in $\mathrm{H}_{2} \mathrm{O}_{2}$ detoxification using the GSH pool (Noctor and others 2014) confirmed this ROS-BRs relationship. PPO catalyzes oxidation of molecules with phenolic groups and is activated during heavy metal detoxification (Zheng and others 2010). The participation of EBR in the activation of oxidative stress-related genes was indicated by Müssig and others (2002). In Ahammed and others (2012) studies, the EBR-stimulated expression of detoxification genes (such as CYP90b3, GSH1, and GST1), responsible for reduced glutathione (GSH) content and glutathione $S$-transferase activity, confirm the significance of BR in regulation of antioxidative enzymes synthesis.

The increase in this enzyme activity in wheat calli may be a reaction to the presence of BRs that contain phenolic groups in their structure.

Significant increases in SOD, CAT, and POD activity following ZEA treatment and mainly in cells of sensitive wheat indicated generation of ROS and was anticipated as a result 
of oxidative stress induction in this mycotoxin presence similarly as it was found in other stressful conditions (Abedi and Pakniyat 2010; Caverzan and others 2012; Sofo and others 2015). Thus, it was expected that the mixture of EBR and ZEA might induce additional rise in antioxidant activity in the calli cells. The observed decrease in the activity of all investigated enzymes to the values obtained for EBR alone confirms that in ZEA-induced stress conditions EBR molecules might serve as antioxidants that limit ROS presence.

The influence of both ZEA and EBR on ROS synthesis was also confirmed in the analysis of MDA concentration. This parameter characterizing lipid peroxidation was slightly higher in control cells of the tolerant genotype as a result of greater lipid unsaturation (ratio U/S). Much more visible changes registered in the cells of sensitive wheat, especially under ZEA treatment indicated that lipid membranes of this genotype were oxidized to a higher degree as a consequence of greater ROS generation. The association between the increase in lipid peroxidation expressed by MDA concentration and ROS synthesis under stress conditions was indicated as an effect of many stressors (Moore and Roberts 1998; Xu and others 2014). The decrease of MDA content observed in the cells of both investigated genotypes in the presence of EBR in ZEA-supplemented media suggested an interaction between these substances also in the hydrophobic environment of a cell membrane.

The measurements of membrane permeability, electrokinetic potential changes, and physiochemical properties of Langmuir monolayers demonstrated that both EBR and ZEA might be absorbed and located in lipid membranes. The decrease of membrane permeability after treatment with the investigated substances may suggest that EBR and ZEA interact with the plasmalemma either by direct blocking of ion channels (receptors) activity or indirectly, by inducing changes in membrane structure (as a result of entering the hydrophobic part of the lipid bilayer). The latter assumption was confirmed by the results obtained in the experiments in model membrane systems. However, major changes in membrane permeability observed in the control cells treated with both substances for only $0.5 \mathrm{~h}$ (as compared with 7-day treatments) suggested that additional effects of their interaction with membrane surfaces (in the first minutes of the reaction) could be an immediate binding with specific protein receptors. Moreover, the changes in electrokinetic potential, yielded by adsorption studies of the substances on the membrane surface, were also greater for short rather than for long treatment. A decrease in electrokinetic potential of the membrane surface is usually the effect of enhanced adsorption of molecules with negatively charged groups that are exposed to the environment. Our earlier studies showed that in the presence of positively charged ions ( $\mathrm{Ca}$ cations) in a medium, ZEA interaction with callus membranes affected the changes in electrokinetic potential towards more negative values, as compared with non-treated control cells (Filek and others 2002). A similar effect for ZEA presence in the measuring media (containing $\mathrm{K}$ cations) was expected in this study. The same direction of changes in electrokinetic potential values observed after EBR addition suggested a similarity between ZEA and EBR interaction with plasmalemma surface. The values of electrokinetic potential obtained for the mixture of ZEA + EBR were close to those of EBR, despite significantly lower concentration of EBR. This indicated that the presence of BRs was an important element in modeling the interactions of these molecules with cellular membranes.

Detailed studies on the interaction of lipid membranes with the investigated substances in monolayer systems allowed us to conclude that both ZEA and EBR may be localized in the hydrophobic part of membranes, similarly to other steroids (Hac-Wydro and others 2007). This location was confirmed by the increase in the distance between lipids $\left(A_{\text {lim }}\right)$, accompanied by higher compressibility of the lipid layer observed in native membranes obtained from callus cells (as well as in model phospholipid monolayers). More pronounced effects found in sensitive wheat, especially under ZEA treatment, may result from greater accumulation of this molecule in the membrane structure. Such an effect may partly explain lower tolerance of these plants to the mycotoxin. The increase in the membrane compressibility in EBR presence may protect cells against incorporation of ZEA.

Both ZEA and EBR added separately did not change the physical state of the membranes defined as liquid-condensed monolayers (based on isotherm progression). The plateau registered for DOPC isotherms for ZEA + EBR presence indicated an appearance of specific solid-condensed domains (Pichot and others 2013) as an effect of interaction between both substances in the membranes. Additional information on the collaboration of ZEA with EBR in lipid monolayers, derived from the calculations of free energy of mixing, may indicate that these relationships differ depending on the ratio of these two substances. The strongest interactions between them, observed when the ZEA concentration was low in comparison with EBR, were manifested as negative values of the free energy of mixing. For more compressed monolayers (higher $\pi$ values), which characterize cell membranes of sensitive wheat (lower U/S ratio), the possibility of ZEA replacement with EBR seems to be less effective due to a strong interaction between them. In more loose membranes of tolerant wheat (higher U/S ratio), EBR may more probably eliminate ZEA from monolayers as their interactions are weaker. 


\section{Conclusions}

The study carried out in in vitro cultures allowed us to speculate on direct reactions of EBR and ZEA with the wheat cells. We found that:

- Non-differentiated cells were characterized by similar quantitative and qualitative content of BRs independent of genotypic tolerance of plants from which in vitro cultures were initiated. For Parabola and Raweta cells these BRs were casta- and homocastasterone,

- the amount of EBR accumulated in the cells depended on the genotype and it was lower in the sensitive cells. However, EBR present in the cells stimulated the same pathways of native BRs synthesis in both genotypes,

- the presence of ZEA (mycotoxin) together with EBR changed the activation of native BRs synthesis pathways in the cells of sensitive wheat towards greater accumulation of castasterone,

- the protective action of EBR in ZEA-induced stress conditions based on a reduction of ZEA uptake was confirmed. The cells of tolerant genotype absorbed greater amounts of EBR and smaller amounts of ZEA (also in EBR presence), and a contrary situation was observed in the sensitive cells (accumulation of higher ZEA and lower EBR amounts),

- EBR presence in the cells may stimulate generation of hydrogen peroxide, a signaling molecule activating specific genes (involved also in a protection against mycotoxins), and

- EBR protection against ZEA involves an activation of the antioxidant system and changes of the physicochemical properties of membranes. EBR, by entering the structure of cell membranes in the tolerant plants (characterized by higher level of unsaturated lipids as compared with sensitive ones), may block ZEA absorption in the lipid layers more effectively than in sensitive plants with more saturated membranes.

Acknowledgements This work was supported by NCN project No. 2014/15/B/NZ9/0219. The authors thank Dr. Ondrej Novák (Laboratory of Growth Regulation, Olomouc, Czech Republic) for technical assistance in UHPLC-MS/MS measurements.

\section{Compliance with Ethical Standards}

Disclosure No potential conflict of interest was reported by the authors.

Open Access This article is distributed under the terms of the Creative Commons Attribution 4.0 International License (http://creativeco mmons.org/licenses/by/4.0/), which permits unrestricted use, distribution, and reproduction in any medium, provided you give appropriate credit to the original author(s) and the source, provide a link to the Creative Commons license, and indicate if changes were made.

\section{References}

Abedi T, Pakniyat H (2010) Antioxidant enzyme changes in response to drought stress in ten cultivars of oilseed rape (Brassica napus L.). Czech J Genet Plant Breed 46:27-34

Aebi H (1984) Catalase in vitro. Method Enzyme 105:121-126

Ahammed GJ, Gao CJ, Ogweno JO, Zhou YH, Xia XJ, Mao WH, Shi $\mathrm{K}, \mathrm{Yu}$ JQ (2012) Brassinosteroids induce plant tolerance against phenanthrene by enhancing degradation and detoxification in Solanum lycopersicum L.. Ecotoxicol Environ Saf 80:28-36

Anuradha S, Rao SSS (2001) Effect of brassinosteroids on salinity stress induced inhibition of seed germination and seedling growth of rice (Oryza sativa L.). Plant Growth Regul 33:151-153

Bajguz A (2000) Blockade of heavy metals accumulation in Chlorella vulgaris cells by 24-epibrassinolide. Plant Physiol Biochem 38:797-801

Bajguz A, Hayat S (2009) Effects of brassinosteroids on the plant responses to environmental stresses. Plant Physiol Biochem $47: 1-8$

Bajguz A, Tretyn A (2003) The chemical characteristics and distribution of brassinosteroids in plants. Phytochemistry 62:1027-1046

Biesaga-Kościelniak J, Filek M (2010) Occurrence and physiology of zearalenone as a new plant hormone. In: Lichtfouse E (eds) Sociology, organic farming, climate change and soil science, vol 3. Sustainable Agriculture Reviews. Springer, Dordrecht, pp 419-435

Birdi KS (1989) Lipid and biopolymer monolayers at liquid interfaces. Wiley, New York

Bligh EG, Dyer WJ (1959) A rapid method of total lipid extraction and purification. Can J Biochem Physiol 37:911-917

Block MA, Dorne A-J, Joyard J, Douce R (1983) The acyl-CoA synthetase and acyl-CoA thioesterase are located on the outer and inner membrane of the chloroplast envelope, respectively. FEBS Lett 153:377-381

Bradford MM (1976) A rapid and sensitive method for the quantitation of microgram quantities of protein utilizing the principle of protein-dye binding. Anal Biochem 72:248-254

Carlberg I, Mannervik B (1975) Purification and characterization of the flavoenzyme glutathione reductase from rat liver. J Biol Chem 250:5475-5480

Caverzan A, Passaia G, Rosa SB, Werner Ribeiro C, Lazzarotto F, Margis-Pinheiro M (2012) Plant responses to stresses: role of ascorbate peroxidase in the antioxidant protection. Genet Mol Biol 35:1011-1019

Chung Y, Choe S (2013) The regulation of brassinosteroid biosynthesis in Arabidopsis. Critical Rev Plant Sci 32:396-410

Dalton DA, Russell SA, Hanus FJ, Pascoe GA, Evans HJ (1986) Enzymatic reactions of ascorbate and glutathione that prevent peroxide damage in soybean root nodules. Proc Natl Acad Sci USA 83:3811-3815

Dhindsa RS, Plumb-Dhindsa P, Thorpe TA (1981) Leaf senescence: correlated with increased levels of membrane permeability and lipid peroxidation, and decreased levels of superoxide dismutase and catalase. J Exp Bot 32:93-101

Ding HD, Zhu XH, Zhu ZW, Yang SJ, Zha DS, Wu XX (2012) Amelioration of salt-induced oxidative stress in eggplant by application of 24-epibrassinolide. Biol Plant 56:767-770

Doohan FM, Brennan J, Cooke BM (2003) Influence of climatic factors on Fusarium species pathogenic to cereals. Eur J Plant Pathol 109:755-768

Fariduddin Q, Yusuf M, Begum M, Ahmad A (2014) 28-homobrassinolide protects photosynthetic machinery in Indian mustard under high temperature stress. J Stress Physiol Biochem 10:181-194 
Filek M, Zembala M, Szechyńska-Hebda M (2002) The influence of phytohormones on zeta potential and electrokinetic charges of winter wheat cells. Z Naturforsch C 57:696-704

Filek M, Biesaga-Kościelniak J, Marcińska I, Macháčkova I, Krekule J (2004) The influence of growth regulators on membrane permeability in cultures of winter wheat cells. Z Naturforsch C 59:673-678

Filek M, Gzyl B, Laggner P, Kriechbaum M (2005) Effect of indole3 -acetic acid on surface properties of the wheat plastid lipids. J Plant Physiol 162:245-252

Filek M, Zembala M, Hartikainen H, Miszalski Z, Kornaś A, WieteckaPosłuszny R (2009) Changes in wheat plastid membrane properties induced by cadmium and selenium in presence/absence of 2,4-dichlorophenoxyacetic acid. Plant Cell Tiss Organ Cult 96:19-28

Filek M, Łabanowska M, Kurdziel M, Sieprawska A (2017) Electron paramagnetic resonance (EPR) spectroscopy in Studies of the protective effects of 24-epibrasinoide and selenium against zearalenone-stimulation of the oxidative stress in germinating grains of wheat. Toxins 9:178. https://doi.org/10.3390/toxins9060178

Flohé L, Günzler WA (1984) Assay of glutathione peroxidase. Methods Enzymol 105:115-121

Gill SS, Tuleja N (2010) Reactive oxygen species and antioxidant machinery in 404 abiotic stress tolerance in crop plants. Plant Physiol Biochem 48:909-930

Gromadzka K, Waskiewicz A, Chełkowski J, Golinski P (2008) Zaeralenone and its metabolites: occurrence, detection, toxicity and guidelines. World Mycotoxin J 1:209-220

Gromadzka K, Waśkiewicz A, Świetlik J, Bocianowski J, Goliński P (2015) Possible way of zearalenone migration in the agricultural environment. Plant Soil Environ 61:358-363

Grzesiak M, Filek M, Barbasz A, Kreczmer B, Hartikainen H (2013) Relationships between polyamines, ethylene, osmoprotectants and antioxidant enzymes activities in wheat seedlings after shortterm PEG- and NaCl-induced stresses. Plant Growth Regul 69:177-189

Gzyl B, Filek M, Dudek A (2004) Influence of phytohormones on polar and hydrophobic parts of mixed phospholipid monolayers at water/air interface. J Colloid Interface Sci 269:153-157

Gzyl-Malcher B, Filek M, Brezesinski G, Fischer A (2007) The influence of plant hormones on phospholipid monolayer stability. Z Naturforsch C 62:55-60

Gzyl-Malcher B, Filek M, Rudolphi-Skórska E, Sieprawska A (2017) Studies of lipid monolayers prepared from native and model plant membranes in their interaction with zearalenone and its mixture with Selenium ions. J Membr Biol 250:273-284. https://doi. org/10.1007/s00232-017-9958-x

Habig WH, Jacoby WB (1981) Assays for differentiation of glutathione S-transferase. Methods Enzymol 77:398-405

Hac-Wydro K, Wydro P, Jagoda A, Kapusta J (2007) The study on the interaction between phytosterols and phospholipids in model membranes. Chem Phys Lipids 150:22-34

Hayat S, Khalique G, Wani AS, Alyemeni MN, Ahmad A (2014) Protection of growth in response to 28 -homobrassinolide under the stress of cadmium and salinity in wheat. Int J Biol Macromol 64:130-136

Infantino A, Santori A, Shah DA (2011) Community structure of the Fusarium complex on wheat seed in Italy. Eur J Plant Pathol 132:499-510

Ioos R, Belhadj A, Menez M, Faure A (2005) The effects of fungicides on Fusarium spp. and Microdochium nivale and their associated trichothecene mycotoxins in French naturally-infected cereal grains. Crop Prot 24:894-902

Janeczko A, Swaczynová J (2010) Endogenous brassinosteroids in wheat treated with 24-epibrassinolide. Biol Plant 54:477-482

Janeczko A, Gullner G, Skoczowski A, Dubert F, Barna B (2007) Effects of brassinosteroid infiltration prior to cold treatment on ion leakage and pigment contents in rape leaves. Biol Plant 51:355-358. https://doi.org/10.1007/s10535-007-0072-2

Janeczko A, Biesaga-Kościelniak J, Okleštková J, Filek M, Dziurka M, Szarek-Łukaszewska G, Kościelniak J (2010) Role of 24-epibrassinolide in wheat production: physiological effects and uptake. J Agron Crop Sci 196:311-321

Joo SH, Jang MS, Kim MK, Lee JE, Kim SK (2015) Biosynthetic relationship between C28-brassinosteroids and C29- brassinosteroids in rice(Oryza sativa) seedlings. Phytochemistry 111:84-90. https ://doi.org/10.1016/j.phytochem.2014.11.006

Kim YS, Kim TW, Kim SK (2005) Brassinosteroids are inherently biosynthesized in the primary roots of maize, Zea mays L. Phytochemistry 66:1000-1006

Kumar KB, Khan PA (1982) Peroxidase in excised ragi (Eleusine coracana cv. PR 202) leaves during senescence. Indian J Exp Bot 20:412-416

Łabanowska M, Filek M, Kurdziel M, Bidzińska E, Miszalski Z, Hartikainen H (2013) EPR spectroscopy as a tool for investigation of differences in radical status in wheat plants of various tolerances to osmotic stress induced by $\mathrm{NaCl}$ and PEG-treatment. J Plant Physiol 170:136-145

Li XJ, Guo X, Zhou YH, Shi K, Zhou J, Yu JQ, Xia XJ (2016) Overexpression of a brassinosteroid biosynthetic gene Dwarf enhances photosynthetic capacity through activation of Calvin cycle enzymes in tomato. BMC Plant Biol 16:33. https://doi. org/10.1186/s12870-016-0715-6

Liu Y, Jiang H, Zhao Z, An L (2011) Abscisic acid is involved in brassinosteroids-induced chilling tolerance in the suspension cultured cells from Chorispora bungeana. J Plant Physiol 168:853-862

Liu Y, Zhao Z, Si J, Di C, Han J, An L (2009) Brassinosteroids alleviate chilling-induced oxidative damage by enhancing antioxidant defense system in suspension cultured cells of Chorispora bungeana. Plant Growth Regul 59:207-214

Lück H (1965) Catalase. In: Bergmeyer HU (ed) Methods of enzymatic analysis. Academic Press, New York, pp 885-888

Malinowski R, Higgins R, Luo Y, Piper L, Nazir A, Bajwa VS, Clouse SD, Thompson PR, Stratmann JW (2009) The tomato brassinosteroid receptor BRI1 increases binding of system in to tobacco plasma membranes, but is not involved in system in signaling. Plant Mol Biol 70:603-616. https://doi.org/10.1007/s1110 3-009-9494-x

McCord JM, Fridovich I (1969) Superoxide dismutase: an enzymic function for erythrocuprein (hemocuprein). J Biol Chem 244:6049-6055

Moore K, Roberts LJ (1998) Measurement of lipid peroxidation. Free Radic Res 28:659-671. https://doi.org/10.3109/107157698090658 21

Murashige T, Skoog FA (1962) A revised medium for a rapid growth and bioassays with tobacco tissues cultures. Plant Physiol $15: 473-479$

Müssig C, Fischer S, Altmann T (2002) Brassinosteroid-regulated gene expression. Plant Physiol 129:1241-1251

Nakano Y, Asada K (1981) Hydrogen peroxide is scavenged by ascorbate specific peroxidase in spinach chloroplasts. Plant Cell Physiol 22:867-880

Nakashita H, Yasuda M, Nitta T, Asami T, Fujioka S, Arai Y, Sekimata K, Takatsuto S, Yamaguchi I, Yoshida S (2003) Brassinosteroid functions in a broad range of disease resistance in tobacco and rice. Plant J 33:887-898

Noctor G, Mhamdi A, Foyer CH (2014) The roles of reactive oxygen in drought: not so cut and dried. Plant Physiol 164:1636-1648

Oklestkova J, Tarkowska D, Eyer L, Elbert T, Marek A, Smrzova Z, Novák O, Fránek M, Zhabinskii VN, Strnad M (2017) Immunoaffinity chromatography combined with tandem mass spectrometry: a new tool for the selective capture and analysis of brassinosteroid plant hormones. Talanta 170:432-440 
Pichot R, Watson RL, Norton IT (2013) Phospholipids at the interface: current trends and challenges. Int J Mol Sci 14:11767-11794

Rudolphi-Skórska E, Sieprawska A (2016) Physicochemical techniques in description of interactions in model and native plant membranes under stressful conditions and in physiological processes. Acta Physiol Plant 38:22. https://doi.org/10.1007/s1173 8-015-2034-1

Rudolphi-Skórska E, Filek M, Zembala M (2014) Physicochemical aspects of reaction of ozone with galactolipid and galactolipidtocopherol layers. J Membr Biol 247:639-649

Schumacher K, Chory J (2000) Brassinosteroid signal transduction: still casting the actors. Curr Opin Plant Biol 3:79-84

Sharma P, Jha AB, Dubey RS, Pessarakli M (2012) Reactive oxygen species, oxidative damage, and antioxidative defense mechanism in plants under stressful conditions. J Bot. https://doi. org/10.1155/2012/217037

Sieprawska A, Filek M, Walas S, Tobiasz A, Mrowiec H, Miszalski Z (2014) Does micro- and macroelement content differentiate grains of sensitive and tolerant wheat varieties? Acta Physiol Plant 36:3095-3100. https://doi.org/10.1007/s11738-014-1666-x

Sofo A, Scopa A, Nuzzaci M, Vitti A (2015) Ascorbate peroxidase and catalase activities and their genetic regulation in plants subjected to drought and salinity stresses. Int J Mol Sci 16:13561-13578. https://doi.org/10.3390/ijms160613561

Suzuki H, Fujioka S, Takatsuto S, Yokota T, Murofushi N, Sakurai A (1993) Biosynthesis of Brassinolide from Castasterone in cultured cells of Catharanthus roseus. J Plant Growth Regul 12:101-106

Tobiasz A, Walas S, Filek M, Mrowiec H, Samsel K, Sieprawska A, Hartikainen H (2014) Evaluation of selenium effect on micro-and macroelements distribution to different wheat tissues during principal plant development stages. Biol Plant 58:370-374

Turcotte JC, Hunt PJB, Blaustein JD (2004) Estrogenic effects of zearalenone on the expression of progestin receptors and sexual behavior in female rats. Horm Behav 47:178-184

Verma A, Malik CP, Gupta VK (2012) In vitro effects of brassinosteroids on the growth and antioxidant enzyme activities in groundnut. ISRN Agron. https://doi.org/10.5402/2012/356485

Xia XJ, Wang YJ, Zhou YH, Tao Y, Mao WH, Shi K, Asami T, Chen $\mathrm{Z}$, Yu JQ (2009) Reactive oxygen species are involved in Brassinosteroid-induced stress tolerance in cucumber. Plant Physiol 150:801-814

Xu Y, Hu W, liu J, Zhang J, Jia C, Miao H, Xu B, Jin Z (2014) A banana aquaporin gene, MaPIP1;1, is involved in tolerance to drought and salt stresses. BMC Plant Biol 14:59. https://doi. org/10.1186/1471-2229-14-59

Yu JQ, Zhou YH, Ye SF, Huang LF (2002) 24-Epibrassinolide and abscisic acid protect cucumber seedlings from chilling injury. J Hort Sci Biotech 77:470-473

Yuan GF, Jia CG, Li Z, Sun B, Zhang LP, Liu N et al (2010) Effect of brassinosteroids on drought resistance and abscisic acid concentration in tomato under water stress. Sci Hortic 126:103-108. https ://doi.org/10.1016/j.scienta.2010.06.014

Zheng L, Cheng Z, Ai C, Jiang X, Bei X, Zheng Y, Glahn RP, Welch RM, Miller DD, Lei XG, Shou H (2010) Nicotianamine, a novel enhancer of rice iron bioavailability to humans. PLoS ONE 5:e10190. https://doi.org/10.1371/jour-nal.pone.0010190

Zullo MAT, Adam G (2002) Brassinosteroid phytohormones-structure, bioactivity and applications. Braz J Plant Physiol 14:143-181 